\title{
An Analysis of Causes for SMEs Financing Difficulty
}

\author{
Hongbo Duan, Xiaojie Han \& Hongbo Yang \\ School of Management, Hebei University \\ Baoding 071002, China \\ E-mail: duanhongbocn@126.com
}

This paper is supported by the project of the development of social science research of Hebei Province: the research of small and medium enterprises in financing difficulties Governance (Item No. 200904019)

\begin{abstract}
SMEs have an extremely important position in national economy and social life, especially in the aspect of solving employment and promoting urbanization, what is irreplaceable by large enterprises. However, at present the SMEs financing issue in China has already become a serious problem that troubles the economic development, market growth, and social progress. This issue has aroused a wide attention from economic theory field, industrial field, and the government. This paper summarizes the causes for SMEs financing difficulty comprehensively, with the hope of offering references for further studies.
\end{abstract}

Keywords: Small and medium enterprises (SMEs), Financing, Cause

\section{Disadvantage conditions for financing}

For SMEs, the conditions for financing are inferior to that of large enterprises.

(1) High transaction costs. To issue loans for SMEs means high costs, which serves as a barrier for banks offering loans for SMEs. Banking credit is a typical scale economy. The larger the loan, the smaller the unit transaction cost.

(2) Information asymmetry. The information asymmetry and incomplete information cause the credit rationing in credit market ------ According to the contract conditions, banks offer the funds less than required. Empirical studies show that, compared with large enterprises, SMEs suffer more from the credit rationing. Reasons are: Firstly, SMEs are at an inferior position in transaction costs. Secondly, SMEs managers do not possess high credits. Their management style and behavioral characteristic have a higher uncertainty, which makes banks face serious moral risks if they offer loans for SMEs. SMEs also face the rationing issue by financing in the security market.

(3) SMEs are at an inferior position in credit filtration. As banks face the adverse selection issue, the active strategy is to put forward certain non-prince condition. In other words, ask the loan applicant to offer mortgage or guaranty by certain mechanism. SMEs face more strict requirements for mortgage in applying loans. Meanwhile, due to the geological location, the special assets, and the disposal cost, SMEs will suffer more loss in liquidation. Only by means of higher requirements for mortgage, can banks compensate the potential loss.

(4) SMEs face greater risks in operation. SMEs usually operate in a short period. The probability of exiting from the market is high, which increases the risks of banks objectively. It is estimated that nearly $23.7 \%$ of small enterprises disappear in two years and nearly $52.7 \%$ of small enterprises exit the market in four years due to business failure, bankrupt, or other reasons.

\section{Worse credit of SMEs and single financing channel}

SMEs have to build up their credit. However, the macro environment in which SMEs live at present has a relative economic surplus. As a result, SMEs grow slowly. And it is hard to accumulate a higher credit. SMEs do not have a wide financing channel. They mainly depend on state-owned banks. However, the state-owned commercial bank does not enter the market completely. Former public-to-public credits will not impact the chief manager due to failure of enterprises. Once the public-to-public credits are in problems, it is hard to settle down the issue. Therefore, with this worry, banks usually set restrictions for issuing loans for SMEs in fields of amount, procedure, mortgage, and so on. Besides, due to the SMEs' great needs, commercial banks cost a lot in operation. So, state-owned commercial banks are not friendly with SMEs in a sense. SMEs do not possess a financing guaranty system. Before, enterprises usually offer guaranty mutually. But at present, the guaranteed financing between enterprises are seldom. After all, it is not necessary for an independent enterprise offering guaranty for other enterprise, which will benefit nothing but increase risks. On 
the other hand, if reformed SMEs are normal stock enterprises, the Law of Enterprise regulates strictly on offering guaranty for other enterprises. Therefore, although after 1998 the government advocates banks to offer services for private enterprises, banks find it not easy due to SMEs' defects: such as the credit issue. For some SMEs, they operate merely based on loans, which worsen the competitive environment and the credit. The relationship between SMEs and banks is not in harmony.

At present, China's finance environment is transferring from the old to the new. Many regulations and laws are imperfect. Policy support for SMEs may not be in work. Financing support is not effective and SMEs could not get sufficient loans from banks.

A survey shows that the loan get by SMEs is about $0.5 \%$ of large enterprises. But in applying loans, SMEs have to follow the complicated procedures similar to large enterprises. For one loan, banks have to take five times of management costs by offering the loan for SMEs than for large enterprises. So, under the circumstance of severe industrial competition and pursuing for maximum profits, banks would like to offer loans for large and medium enterprises.

\section{The direct financing channel for SMEs is almost closed}

The security market is crowded by state-owned enterprises. SMEs could not occupy any position in the market. Few SMEs can enter the market by reforming into stock enterprises. Private financing is regulated strictly in China because it may cause a series of social problems. The government is careful for the development of private financing. The Criminal Law regulates the "illegal private financing crime" seriously. As a result, SMEs face demanding political barrier in direct financing. Therefore, on one hand, amounts of private capitals could not be used effectively. They have to flows into state-owned enterprises by commercial banks. On the other hand, SMEs are lack of capitals. They could do nothing but stand by. China does not open the enterprise property right market. Enterprises' assets could not flow freely. Some enterprises fail to make best use of their assets. Some enterprises have to develop by their own assets instead of by merger and purchase. To sum up, because of the lack of a capital market, the development of SMEs seems to be primitive.

In China's financial system, the capital market, compared with the fund market, is imperfect. It lacks of a multi-level capital market that can offer financing services for SMEs. The domestic main board market is only for state-owned large and medium enterprises' financing. The second board market is still a beautiful wish. The third board market grows by itself slowly. Foreign second board market is too far to be helpful. Present laws and regulations on listing financing and issuing securities are not good for SMEs. It is hard for SMEs to get funds by direct financing, such as debts or stock financing.

\section{Funds and guaranties are useless}

"Banks always lend money for people who do not need money." Rich people can offer asset guaranty. SMEs have not sufficient assets. They could not take effective assets as guaranty. In order to escape from risks, banks will not offer loans for SMEs if without effective guaranty even they feel optimistic to certain SME's development.

At present, many SMEs adopt the mutual private guaranty in order to obtain capitals. The advantages are lower requirements, easy operation, and wide adaptation. But once there is a problem, two sides may be hurt. Risks are large.

Although recently some guaranty funds can offer financing services for enterprises, the quantity and the scale of present guaranty institutions are small. They do not desire for offering credit guaranty. It is estimated that China's guaranty system can offer the guaranty for 50 billion Yuan every year. Compared with millions of SMEs' thousands of billions financing needs, it merely solves no more than 5\% capital short. Presently, most guaranty institutions are at loss. The long-term development capability is weak. Besides, guaranty funds may be troubled by political interference. They could not escape from risks. Therefore, they have to operate carefully. They set strict requirements and complicated procedures for enterprises' guaranty, which increases enterprises' burden, missing business opportunities. So, the credit guaranty institutions could not support SMEs effectively. In a short period, they will not help a lot.

\section{It is not easy to depend on enterprises' self accumulation or leaders' personal credit}

Qi Zhao, the vice president of Yuyang Group, has said: "The bank always loves the rich the hates the poor. If you have more assets, he would like to marry his girls to you. If you just start your business, he would not give you money by all means. SMEs should not hope to get money from banks." This phenomenon is common at present. Under the condition of no indirect financing and direct financing, private enterprises have no choices but financing by themselves.

In the severe competitive environment, it is hard for SMEs realizing the primitive capital accumulation due to the lower interests and profits.

Although financial supervision agencies impose strict control over private financing, the private credit market is still active. It is difficult for private enterprises financing by this way. Sometimes, they may commit crimes. The Dawu Sun case is a typical example. Dawu Sun has ever worked in credit cooperatives and Agricultural Bank of China. But he still 
failed to get loans from banks. Therefore, he had to get capitals by himself. His enterprise started from a waste land. Finally, he was sued. Now, he was judged for three years imprisonment, delaying an execution of four years.

Another direct financing for private enterprises is stock financing. However, the stock right can not flow freely among stock enterprises. And enterprises suffer burden of allocating dividends for small and medium stockholders. As a matter of fact, in order to create the positive development expectation and enhance enterprises' cohesion, enterprises try their best to allocate dividends. As a result, enterprises will be in short of capitals. Seldom enterprises input capitals in R\&D.

\section{Restriction of financing characteristics}

The financing of SMEs is usually featured with "small, frequent, and fast". SMEs are sensitive to the market. Once they find business opportunities, they apply loans from banks. And they ask banks to offer loans as soon as possible in order to organize materials and realize transactions in time. However, state- owned commercial banks have to follow strict procedures and operational standards before issuing loans, which could not satisfy SMEs' needs for financing.

\section{References}

Fan, Wenyan \& Liu, Zonghua. (2005). On the relationship between financing structure and governance structure. Finance \& Economics, No.5.

Han, Zhiguo. (2007). Institutional Defaults of China Capital Market. Beijing: Economic Science Press. April.

Huang, Shaoan \& Zhang, Gang. (2007). Analysis of China's public companies' stock financing bias. Economic Studies, No.11.

Zhong, Hua. (2008). How small and medium enterprises make market investigation. China Small Medium Enterprises, No.2. 